\section{Escape Routes: Further Adventure Writings of David Roberts}

David Roberts

Seattle, WA: The Mountaineers, 1997

US \$22.95 hardcover, US \$16.95 softcover, 267 pages.

In a glut of adventure narratives that cover the spectrum of extreme, gravity, or adrenaline sports, it is refreshing to read one so well written by a writer so broadly experienced as David Roberts This compilation is his more recent collection of articles that first appeared in Outside, Men's Journal, Smithsonian, and other magazines.

Roberts first wrote mountaineering narratives when he climbed in Alaska with the Harvard Mountaineering Club. His first books, Deborah: A Wilderness Narrative and The Mountain of My Fear, are still in print. Roberts went on to become one of the foremost adventure travel and outdoor sports writers. His works range from writings on the Anasazi of the American Southwest to a biography of writer Jean Stafford. Like his colleague, friend, and onetime pupil Jon Krakauer, who wrote the forward to this book, he defined the genre.

The works in this volume range from caving in Mali to river rafting in Ethiopia, searching for ancient peoples of the American Southwest, climbing in Iceland, adventure racing in Patagonia, and rock climbing in Switzerland. A few are about people, like that of high-profile, high-altitude climber Ed Viestures and the more subtle adventurer and teacher Roman Dial.

The stories are spiced with well-researched historical information and packed with adventure. Not as emotionally engaging as Krakauer or as funny and hare-brained as the other king of adventure narrative, Tim Cahill, Roberts is a regular guy and good writer to boot.

Christopher Van Tilburg White Salmon, WA, USA

\section{Wild Snow: A Historical Guide to North American Ski Mountaineering}

Louis W. Dawson

Golden, CO: American Alpine Club, 1997

US \$40.00 hardcover, US \$24.95 softcover, 292 pages.

Louis W. Dawson took on a task that has made mountaineering writers envious: to collect and document the history of ski mountaineering in the United States and add in 54 of the greatest descents. The hybrid book is half history text and half guidebook. This is a daunting and complex task for a niche market.

Dawson has appropriate introductory and appendix material, but the bulk of the text is geographically organized. Nine general areas make one yearn for wilderness snow and big turns: The Sierra and San Gabriel Mountains in California, the Pacific Northwest's Cascade Range, British Columbia's Coast Mountains, Alaska peaks and Canada's Yukon, Canadian Rockies, Wyoming's Tetons, Utah's Wasatch range, Colorado's Rockies, and the mountains of the Northeast. Interestingly, he did leave out some rideable peaks in Mexico.

From the historical perspective, Dawson includes lots of photographs from the American Alpine Club and other archives. For the routes, he details information as found in any guidebook, such as elevation, mileage, maps, reference books, weather, and any red tape that should be expected. The descents are a dream list for ski and snowboard mountaineers, including classics like Mount Rainier in Washington and the legendary Y Couloir in Utah's Little Cottonwood Canyon.

A noteworthy point, Dawson defines glisse alpinism, a term he coined in magazine articles. Stemming from the French glisser (to slide), Dawson defines it as gliding down snow on an edged tool, including alpine touring, telemark skiing, firn gliding, and snowboarding. And Dawson is no armchair writer, he was the first to ski all 54 of the 14000 -foot peaks in Colorado, and he wrote 2 guidebooks covering them. What's his next project?

Christopher Van Tilburg, MD White Salmon, WA, USA 